Title: Suicidal thoughts in the novels of Anthony Trollope (1815-82)

Authors: Pridmore S.; ${ }^{1}$ Auchincloss S.; ${ }^{2}$

Type: Original article

Keywords: Suicidal thoughts;

\title{
Abstract
}

Background: Suicide is a leading cause of death but incompletely understood.

Aims: To extend our understanding of suicide antecedents (suicidal thoughts and other suicide representations) by examining the novels of Trollope, and drawing comparisons with current experience.

Method: Five novels and An Autobiography were examined. Text events were collated under headings, 1) suicidal thoughts, and 2) other suicide mentions. Details were gathered of triggers, methods of suicide, and related material.

Results: Twenty-two events of characters experiencing suicidal thoughts, and 25 other mentions of suicide were identified. The main methods were shooting, jumping and drowning. The triggers were romantic disappointment, poverty and loss of wealth, and disgrace. Mental disorder was mentioned only once.

Conclusion: Trollope depicted suicidal thoughts as a response of healthy individuals to distress, and methods similar to the present. This new information extends our knowledge of the history of suicide and argues for a range of triggers.

\footnotetext{
1 Saxby Pridmore, MD, FRANZCP, Discipline of Psychiatry, University of Tasmania, Australia.

2 Stephane Auchincloss, MRCP, FRANZCP, Discipline of Psychiatry, University of Tasmania, Australia.

Correspondence: Prof S Pridmore, Discipline of Psychiatry, University of Tasmania, Private Bag 34, Hobart, Tasmania 7001, Australia. Mail: S.Pridmore@utas.edu.au
} 


\section{Suicidal thoughts in the novels of Anthony Trollope (1815-82)}

Suicidal thoughts refers here to thoughts an individual has about taking his/her own life. It includes lesser phenomena than suicidal ideation, when defined as 'seriously thought about suicide'. ${ }^{1}$

Suicide attempts are strongly predictive of completed suicide, ${ }^{2}$ but to our knowledge, there is no report of the strength of suicidal thoughts in predicting this outcome. However, all purposeful action is preceded by thought, and knowledge of the suicidal behaviour of another significantly increases the risk of similar behaviour, ${ }^{3}$ suggesting option awareness influences behaviour.

A study of 17 developed and developing countries found a lifetime prevalence of suicidal ideation of $9.2 \% .{ }^{4}$ A study using the Australian National Survey of Mental Health and Wellbeing of 2007 found a lifetime prevalence of suicidal ideation of $13.3 \%$ and a one year prevalence of $2.3 \%{ }^{1}$

Suicide has been demonstrated in every region and time, and is associated with biological, psychological and social trigger factors. Nevertheless, our understanding of suicide and its antecedents is incomplete, and there is some danger of exclusively focusing on mental illness and the medical model. ${ }^{6}$

Literature reflects the culture of a region at the time of its creation, and impacts the culture of the future. In addition to non-fiction, fiction explicitly conveys social values ${ }^{5}$ and provides a response repertoire. Naturally, the style and characteristics of each individual author and the period must be considered in any assessment.

The objective of this study is to extend our understanding of suicide antecedents (suicidal thoughts and other suicide representations) by examining representations in the Victorian England novels of Anthony Trollope (1815-1882) and drawing comparisons with features of the present time.

\section{The Life of Trollope}

Trollope is prominent in the second rank of novelists of his time (behind Dickens, Thackeray, and George Elliot). He lived during a long period of peace, prosperity and refined sensibilities in Britain. His father was an unfortunate man, "The touch of his hand seemed to create failure" $^{7}$ (p. 31) - failing both at the law and on the land. The boy was born into a 
privileged class but without sufficient means. He attended elite schools (Harrow and Winchester College) but describes being "poor, friendless and joyless" (p. 132) and states "I had not only no friends, but was despised by all my companions"” (p. 11).

Trollope secured a position at the Post Office, but found his income insufficient for a life of modest comfort. His mother was an author and he decided to become a novelist, primarily to supplement his wages. He resigned from the Post Office at 52 years of age. He was highly disciplined and from his early 20's till old age, he arose early every morning and wrote a set quota of pages. He was happily married, and had a small family. His autobiography ${ }^{7}$ which he arranged for posthumous publication gives precise details of the profits of every publication and his fox hunting exploits, but tells nothing of his children. He enjoyed literary and financial success, reputation and the friendship of publishers and other authors; he writes, “...who has had a happier life than mine?”7 (p. 60)

\section{His Mental Health}

At 12 years of age, Trollope had thoughts of suicide - "How well I remember all the agonies of my young heart; how I considered whether I should always be alone; whether I could find my way up to the top of that college tower, and thence put an end to everything?"7 (p. 9) He was aware of the act of suicide from a young age as a student in his father's law chambers killed himself. ${ }^{7}$ (p. 3) There is no evidence that Trollope suffered a psychiatric disorder and no suggestion of suicidal thoughts during his adult years.

He suffered financial privation as a child, and throughout life he sought financial security. His father was unsuccessful, but Trollope was disciplined and industrious. He was independent, but enjoyed his wife, family and friendships, and admits to valuing "the charms of reputation”. ${ }^{7}$ (p. 107) He had a strong "sense of right and wrong” ${ }^{7}$ (p. 183) and believed the author had the responsibility "to teach wholesome lessons". ${ }^{7}$ (p. 224)

\section{His Work}

Trollope was a prodigious, writing 47 novels, some travel and history, many short stories and an autobiography.

He believed that the "primary object of the novelist is to please" ${ }^{7}$ (p. 248) and that his/her work should "be readable”. ${ }^{7}$ (p. 349) He held that "men’s conduct will be actuated by that which is from day to day depicted to them", ${ }^{7}$ (p. 221) leading to statements that the novelist "must teach whether he wish to teach or no" and "must preach his sermons with the same 
purpose as the clergyman, and must have his own system of ethics”. ${ }^{7}$ (p. 222) For his readers he aimed to "make virtue alluring and vice ugly", 7 (p. 222) and for himself, "to have the sweet and leave the bitter untasted”. ${ }^{7}$ (p. 366) His novels have pleasant plots and happy endings, which contributes to their popularity.

Trollope aimed at realism (with romanticism) - "A novel should give a picture of common life” $^{7}$ (p. 126) with "inhabitants going about their daily business”, ${ }^{7}$ (p. 144) such that "readers might recognize human beings like to themselves". ${ }^{7}$ (p. 145) He paid particular attention to personality - "human nature must be the novel-writers guide”, ${ }^{7}$ (p. 240) and strove to "create personages impregnated with traits of character which are known". ${ }^{7}$ (p. 126) He sought "truth of character, human truth as to men and women", 7 (p. 229) and complemented himself on his creations - "I doubt whether such a character could be more lifelike". ${ }^{7}$ (p. 143)

\section{Method}

Five Trollope novels (The Warden, 1855; Barchester Towers, 1857; Can You Forgive Her? 1865; Phineas Redux, 1874; Cousin Henry, 1882) were selected solely on availability - 2 were owned by the authors and 3 were found in book shops. These texts were examined for events touching on suicide. Events were collected under two headings, 1) suicidal thoughts in which a particular individual had a thought about ending his/her life, which could have been a first step toward suicide, and 2) other suicide mentions - not necessarily connected to a particular individual, but bringing the topic to the awareness of readers. Events were counted rather than individuals, and those who experienced suicidal thoughts more than once (at different places in the text) contributed progressively to the total. We also noted the described triggers (including mental disorder) and possible methods, and searched for accounts of completed suicide and other related material.

\section{$\underline{\text { Results }}$}

In about 900000 words, in 5 novels published between 1855 and 1879, there were 22 examples of suicidal thought and 25 other suicide mentions. In both there was a 
preponderance of males, 12 males versus 10 females and 17 males versus 8 females, respectively. The main methods were shooting, falling from a height and drowning, with rare listings of hanging, poisoning and stabbing. The suicide triggers were romantic difficulties, poverty and loss of wealth, and public disgrace, which commonly co-occurred. There was one suggestion that Public Servants may be driven to suicide by work conditions. ${ }^{8}$ (p. 584) We found no account of completed suicide.

Mental disorder was not linked to any example of suicidal thought, and feature in only one other suicide mention - this was a paranoid man (Mr Kennedy) whom it was feared may “attempt to destroy himself”. (p. 190) One man (Mr Vavasar) fantasised about murdersuicide. ${ }^{8}$ (p 579)

Thus, in the novels of Anthony Trollope, the model of responding to disappointment and difficulties with suicidal thoughts was clearly and frequently detailed, and the topic of suicide was not-infrequently mentioned.

There was acknowledgement that disappointment could lead to reckless behaviour. A man (Mr Maule) was disappointed in gaining access to his ancestral property, but he "was not vicious, he neither drank nor gambled, nor ran himself hopelessly into debt”. ${ }^{9}$ (p. 229) And, the belief was expressed that one could die of disappointment - "Mumma would lie down and die if she had not her own Johnny Bold (her baby) to give her comfort”. ${ }^{10}$ (p. 489)

\section{Examples}

The Warden (1855; words, 70 000)

1. Suicidal thoughts: 1 case (p. 108).

A young man (Mr Bold) was in turmoil. He was exposing what he considered to be corruption - but, he was in love with the daughter of the man who would be most injured by his activities. "Sometimes (he thought)... he would blow out his brains and have done with all his cares". ${ }^{11}$ (p. 108)

2. Other suicide mentions: 1 case (p. 88).

A clergyman (Mr Harding) was criticized in the press. "Why should he not die, for he felt he could not live, under the weight of obloquy?”"11 (p 88) 
Barchester Towers (1857; words, 209 000)

1. Suicidal thoughts: 2 cases (pp. 224 and 369).

A clergyman (Mr Arabin) could not stop himself thinking about two attractive women. He tried to stop thinking of the first, but he "went on thinking about her till he was almost in a state to drown himself in the little brook." He then could not stop thinking of the second "and so flung stones into the brook, instead of flinging in himself”. ${ }^{10}$ (p. 369)

2. Other suicide mentions: 7 cases (pp. 20, 285, 298, 374, 423, 448 and 556).

At a gathering, a young widow asked a man's sister of his whereabouts. He ( $\mathrm{Mr}$ Stanhope) was in love with the widow. The sister replied that he had seen the widow talking to another man "and is now on the point of hanging himself". ${ }^{10}$ (p. 448)

Can You Forgive Her? (1865; words, 320 000)

1. Suicidal thoughts: 12 cases (pp. 234, 275, 351, 397, 405, 431, 463, 552, 562, 631, 686 and 765).

The heroine (Alice) was determined to avoid marriage to a particular suitor. "While there was a cliff from which she might fall, water that would cover her, a death-dealing grain that might be mixed in her cup, she would not submit herself to be George Vavasor's wife". ${ }^{8}$ (p. 351)

2. Other suicide mentions: 9 cases (pp. 314, 478, 570, 579, 584, 681, 688, 728 and 731). An innkeeper says of a distressed man (Mr Fitzgerald), "Perhaps with his own hand he will kill himself”. ${ }^{8}$ (p. 731)

Phineas Redux (1874; words, 248 000)

1. Suicidal thoughts: 4 cases (pp. 15, 294, 515 and 602)

The hero (Phineas) was a recent widower whose prospects for wealth and position appeared to be fading. "There was always the bare bodkin (reference to a dagger)...fall overboard...may do it in a cunning fashion that his friends shall thing that it was an accident”. ${ }^{9}$ (p. 15)

2. Other suicide mentions: 5 cases (pp. 98, 158, 190, 306, and 601)

A Lady (Laura) reveals to Phineas her secret love for him. "I could have put a pistol in my ear sooner than speak as I have spoken”. 9 (p 98) 
Cousin Henry (1879; words, 68 000)

1. Suicidal thoughts: 4 cases (pp. 146, 153, 165 and 167).

The antihero (Henry) had been deceptive and was terrified of being cross-examined. "It would be easier for him to throw himself onto the rocks...than to go into a court of law”. ${ }^{12}$ (p. 146)

2. Other suicide mentions: 3 cases (pp. 128, 204 and 225).

The heroine (Isobel) was in love with a man but would not marry him as she had taken a position according to her conscience. "To go and die and have done with it, if that might be possible, was the panacea of her present troubles most commonly present to her mind."12 (p. 128).

\section{$\underline{\text { Discussion }}$}

\section{Limitations}

Only 5 of 47 novels were studied. It is unlikely, however, that the remaining novels differ greatly, and even if they do, that would not negate our findings with respect to the 5 examined.

The use of two categories, suicidal thought and other mentions of suicide is unprecedented and somewhat arbitrary. Our ambition was to determine whether the concept of suicide had been made available to the readers at the time of publication (and subsequently). We believe the division is justifiable as the first category could be expected to have greater impact on the reader than the second. These categories could be collapsed without altering our findings.

Another limitation is that the categorization of text events was subjective. For example, a man (Henry) was desperate to avoid court cross-examination and thinks, "Oh, if he could but die! If the house would fall upon him and crush him!”12 (p. 204) Here there is no mention of the word suicide or the taking of action to secure death. We classified this as an example of 'other suicide mention', others may have done differently.

\section{Relevance of findings}

We have shown that in the Victorian era, in the novels of Anthony Trollope, the model of responding to distress with suicidal thought was clearly and frequently detailed. In the 5 novels we examined there were 22 examples of distress followed by suicidal thoughts, 
supported by 25 other mentions of suicide. In only 1 of these 47 text events was there evidence of mental disorder, thus, the model was a possible response option for mentally healthy individuals. We contend the works of Trollope reflect the behaviour of his time, as he believed that "A novel should give a picture of common life"7 (p. 126) We also contend that these models impacted on the behaviour of readers. On this point Trollope believed that "men's conduct will be actuated by that which is from day to day depicted to them", 7 (p. 221) and recent evidence indicates that fiction explicitly conveys social values. ${ }^{5}$

Trollope described 22 episodes of suicidal thoughts. While no quantitative comparison can be attempted, population studies of the present day find a lifetime prevalence of suicidal ideation in 17 developed and developing countries of $9.2 \%,{ }^{4}$ and in Australia of $13.3 \%,{ }^{1}$ thus they are by no means rare.

The methods named by Trollope were shooting, falling from a height, drowning, hanging, poison and stabbing; triggers included romantic difficulties, poverty and loss of wealth, and public disgrace, which commonly occurred together. There was one mention of contemplated murder-suicide arising from anger and resentment. These details are remarkably reminiscent of clinical experience of the present day.

The notion that suicide is a disease or a symptom of disease was stated in the first half of the $19^{\text {th }}$ Century, ${ }^{13}$ became the orthodox medical position and remains so, in many quarters to the present day. ${ }^{14}$ We have shown that in the second half of the $19^{\text {th }}$ Century at least one novel author observed that non-mentally disordered people may respond to distress with suicidal thoughts, and transmitted such models to his readers. Thus, the medical position was not automatically embraced by novelists.

This new material is limited to the Victorian era (1837-1901), however it is an important link in our chain of knowledge and understanding of suicide and related behaviour. The current authors have demonstrated that contemporary authors present similar pictures, ${ }^{15,16}$ suggesting that for healthy individuals in settings of distress, suicidal thoughts in may not be an uncommon response.

Trollope portrayed mental illness in only $2 \%$ of the combined categories of suicidal thoughts and other suicide mentions. This impresses as extremely low, however, one careful population study found that of those who experienced suicidal ideation in the preceding year, only $8.3 \%$ had any form of mental disorder, ${ }^{1}$ and another found $67 \%$ of those who were 'suicidal' (ideation and nonfatal behaviour) did not have depressive disorder. ${ }^{18}$ 
Research has not demonstrated a statistical association between suicidal thought and completed suicide; however, most would agree there is a link between suicidal thought and non-fatal suicidal acts, which are a significant public health problem in their own right, and do increase the risk of completed suicide. ${ }^{1}$

The Victorian era has been described as one of peace and prosperity. However, it followed the Industrial Revolution (1760-1840), which Durkheim ${ }^{17}$ described as a period of anomie and increased completed suicide. It is possible this chronological arrangement may have increased Trollope's awareness of such behaviour.

Whether Trollope's novels are similar or different to other authors to his time remains to be determined. He suffered in his childhood because of his father's repeated failures and inability to financially provide for his son (who attended exclusive schools with the children of well-to-do parents). He was also aware, from an early age, of the notion of suicide due to a self-killing in his father's law chambers. Trollop’s work, however, is not unusually maudlin or morbid. On the contrary, he believed he should "teach wholesome lessons" ${ }^{7}$ (p. 224) and his pleasant plots and happy endings contributed to his sales success. He wrote of the "higher classes", 7 (p. 181) frequently describing the social and working life of the landed gentry, politicians and the clergy. While his school years were unhappy, he married and had a family, held a good job for many years, wrote industriously, was successful and regarded himself as having been fortunate.

\section{Funding}

Nil.

\section{Acknowledgements}

Nil.

\section{Declaration of Interest}

None. 


\section{References}

1. Johnston A, Pirkis J, Burgess P. Suicidal thoughts and behaviours among Australian adults: findings from the 2007 National Survey of Mental Health and Wellbeing. Aust N Z J Psychiatry 2009; 43:635-643.

2. Cavanagh J, Carson A, Sharpe M, Lawrie S. Psychological autopsy studies of suicide: a systematic review. Psychol Med 2003; 33: 395-405.

3. De Leo D, Cerin E, Spathonis K, Burgis S. Lifetime risk of suicide ideation and attempts in an Australian community: prevalence, suicidal process, and help-seeking behaviour. $J$ Affect Disord 2005; 86: 215-224.

4. Nock M, Borges G, Bromet E et al. Cross-national prevalence and risk factors for suicidal ideation, plans and attempts. Br J Psychiatry 2008; 192: 98-105.

5. Kidd D, Castano E. Reading literary fiction improves theory of mind. Science 2013; 342 no. 6156: 377-380.

6. Fitzpatrick S, Kerridge I. Challenges to a more open discussion of suicide. Med J Aust 2013; 198: 470-471.

7. Trollope A. An Autobiography. Oxford: Oxford World Classics, 2008. (First published, 1883)

8. Trollope A. Can You Forgive Her? Vintage, 2012. (First published, 1865)

9. Trollope A. Phineas Redux. Penguin Books, 2003. (First published, 1874)

10. Trollope A. Barchester Towers. Collins Clear-type Press, Library Classics, 1950. (First published, 1857)

11. Trollope A. The Warden. Vintage, 2012. (First published, 1855)

12. Trollope A. Cousin Henry. Oxford University Press, The World's Classics, 1929. (First published, 1879)

13. Esquirol E. Suicide. In Dictionnaire des Sciences Médicales (eds. Adelon, Alibert et al.): 213-83. Panckouke. 1821.

14. Jamison K. Night Falls Fast: Understanding Suicide. Vintage Books, 1999.

15. Pridmore S, Walter G. Does art imitate death? Depictions of suicide in fiction. Australas Psychiatry 2013; 21: 65-72.

16. Pridmore S, Auchincloss S, Soh N, Walter G. Four centuries of suicide in opera. Med J Aust 2013; 199: 783-786. 
17. Durkheim E. Le Suicide. Alcan, 1897.

18. Rhodes A, Bethell J, Bondy S. Suicidality, depression, and Mental Health Services use in Canada. Can J Psychiatry 2006; 51: 35-41. 